\title{
Fictionalised Reality? : Interrogating the Validity of Truth in Muriel Spark's The Ballad of Peckham Rye
}

\author{
Dr. Lin, Hsin-Ying \\ Associate Professor Department of Foreign Languages and Literature National Chung Cheng University, Chia- \\ Yi, Taiwan
}

*Corresponding Author: Dr. Lin, Hsin-Ying, Associate Professor Department of Foreign Languages and Literature National Chung Cheng University, Chia-Yi, Taiwan.

\begin{abstract}
Muriel Spark's The Ballad of Peckham Rye (1960) ruptures time and blurs the boundary between reality and illusion. The story of lower-class life in an industrial suburb south of London is undercharged by the 'balladic' demonic villain (or hero?), Dougal Douglas. This controversial duality of a Satanic (evilseductive) character who invokes fantasy into daily life is characteristic of Muriel Spark's delight in playing the game of fiction and realism, and of her refusal to follow the traditional time scheme of fiction. My argument in this paper will centre on the implication of the boundary between fiction and realism, and on how this implication contributes to the justification of a villain as a demonic hero. If there exists only one question, it might be: who are the villains who are making chaotic rumors? If the deceptions are a reflection of human desires, we may ascertain that fiction is another name for lies, and that the liar as a Satanic character can be regarded as a demonic hero, for he exposes human moral disease. I shall analyse how Dougal's invented 'advice' implicates Peckham residents' gender treatment and confuses individual recognition of the 'truth'. I will then further explore the linguistic intertextuality of The Ballad and Frankenstein, specifically in terms of the satirical demonic spirit.
\end{abstract}

Key Words: Muriel Spark, realism, fiction, truth, satirical demon

\section{INTRODUCTION}

Dougal posed like an angel on a grave which had only an insignificant

headstone. He posed like an angel-devil, with his hump shoulder and

gleaming smile, and his fingers of each hand widespread against the sky.

She looked startled. Then she laughed.

(The Ballad of Peckham Rye, 30)

After examining male maternal abjection and the search for an idealised female body in Thompson's novels, I now choose Muriel Spark's The Ballad of Peckham Rye (1960) to reflect upon two other dimensions related to male anxiety over women: sexuality and familial intimacy. Of all the novels written by Spark, the illusion between reality and imagination has often been the most alluring feature for her readers. A. L. Kennedy has also dealt with this in So I am Glad, thus allowing her female protagonist to engage in mysterious communications with a ghost figure who has with the same sense of isolation and unfamiliarity. The indifference to the external violence allows Kennedy's characters on the way to their self-recovery of the trauma, by interactions with different sex, but with the same mental symptom. When contrasted with Kennedy's work, Muriel Spark's illusion seems to possess the destructive power of an external world of indifference (resulting from internal violence and coming before the construction of self-knowledge). Her illusion, however, also functions to unmask human indifference beyond a sense of fear concerning the other sex.

Spark's The Ballad of Peckham Rye exemplifies the idea of male blind illusion for maternal love under the control of patriarchy, along with the fear of an over-familiarity with women and with himself. Spark was writing decades before Kennedy. This may perhaps explain why she chooses a male devilish character to show other men's problems in gendered relationship and also in Douglas himself. Kennedy at the end of the twentieth-century counts more on the mutual cure between the two 
sexes than does Spark. She makes a lost woman living in a contemporary era, annoyed with media's indifferent reports of social violent incidents without real human concerns. Her female protagonist encounters with an over-idealistic military ghost in the seventieth century, who possesses not only the passions towards national military creeds but also anihilist's sense for life. We may say that while Spark trusts the function of devilish character's destructive power on the way to healthy revolution of the world more, Kennedy expects more of the obliteration of the internal obstacles existing in the gender relationship.

Muriel Spark's The Ballad of Peckham Rye exhibits traits which qualify the devil figure for a mythic mission to bring 'vision' to the gritty industrialised town of Peckham. Dougal turns ordinary town events into extraordinary fantasy. Hired by one of the town's textile plants to take charge of 'human research', Dougal sets out to discover the town's spiritual well - it is glorious history. Once he has observed and classified the kinds of morality he finds in Peckham, Dougal is convinced that 'the moral element lay at the root of all industrial discontents ... ' (82). 'Vision' (64) is an all-consuming concept for Dougal. As used in the novel, it connotes the ability to see past the existent world and to reconstruct a superior one in its place. This spiritual concept is (in his view) 'the first requisite of sanity' (64), and he judges from the character of the company's personnel director. He declares that every person has such a 'fatal flaw' (42). In Spark's Ballad, these fatal flaws are shown to readers through conversations that take place between / among characters, rather than by indications provided by a narrator. Spark pointed out in an interview that this novel is narrated without any expressed feelings and thoughts, because 'feelings and thoughts are even more emphasised when you don't mention them'. ${ }^{1}$ Thus, readers are offered a series of incidents and conversations tinged with the moral values held by each character. It is this moral ambiguity that colours Spark's novel; and these moral values that are left by Spark intentionally to be judged openly by her readers. Is Dougal a mirror, a projection of the long-term pressured minds of Peckham residents? If Dougal's provocative human experiment entails the hidden male abjection of the female body, how does this abjection manifest itself in a desire-filled but also fearful gender relationship?

Muriel Spark is profoundly at odds with 'publically-granted' codes of morality in The Ballad of Peckham Rye. As Hélène Cixous says, 'A macabre cheerfulness springs up from the complete absence of values'. ${ }^{2}$ The pleasure of mocking the secular moral values does not come from their comparison with the counter ones, but from the sheer exhibition of their odds. Spark will never tell her readers what moral value is reproached and what deserves applause; instead, she merely displays the characters' beliefs and leaves ironic discovery to her readers. Spark's narrative achievement resides in the capacity of her readers for reflection and introspection. The Ballad consists largely of conversations that show the moral values of each character; many characters' dialogues concern the devil figure, Dougal Douglas. As a monstrous character, Dougal is much more an outsider of the industrialised community than an evil-doer within it. In other words, his devil-like character triggers, rather than produces, the revelation of the evil motives inherent to certain other characters.

This particular marriage between the monstrous and the human has a thematic significance with regard to the boundary between reality and illusion; this significance seems more familiar to us as we trace this literary heritage back to Mary Shelley's Frankenstein (1818). Frankenstein's monster, abandoned by his creator and outlawed by all who meet him, threatens his creator as well as human society. In this way, Mary Shelley stresses that the monster's existence, as an embodiment of devilish fantasy, is not only inevitable but blameful not only to Frankenstein but to society as a whole. The monster, as a physical anomaly, is a social pariah and a sexual outlaw. In Frankenstein, we may analyse the power and dangers associated with the psychological expulsion of the feminine. Shelley's narrative tests the limits of racial and sexual discrimination, finding each one to be inextricably bound to the other and determining both to be essential for defining the perverse and the unnatural.

I will then investigate this devilish fantasy in daily experiments as they are illustrated in the novel, showing the connection between this version of fantasy and Kristeva's view of gender abjection. I will argue in this paper that a devilish character may induce the evil motives that are embedded in the society around him and may thus misdirect social behaviour. I contend that the boundary between

\footnotetext{
${ }^{1}$ Hosmer, Robert. 'An Interview with Dame Muriel Spark'. Salmagundi. (Spring 2005): 127-158. p. 147.

${ }^{2}$ Hélène Cixous. 'Grimacing Catholicism: Muriel Spark's Macabre Farce'.Theorising Muriel Spark: gender, race, deconstruction. Ed. Martin McQuillan.(New York: Palgrave, 2002), pp. 204-209 (205).
} 
reality and fiction does not really exist in the novel, since the varieties of fiction uttered by characters are precisely the realities that they recognise (though they may sometimes conceal their fictional aspects). Most importantly, 'reality' is nothing more than the projection of mental realities.

I shall explain why Spark's The Ballad is a social satire of Mary Shelley's Frankenstein and why Kristeva's view of intertextuality can function within a comparison of intertextual deviation in The Ballad and Frankenstein in terms of the intertextual deviation. In the third section (7.3), I will intertextually explore The Ballad plot's deviation from that of Frankenstein; by satirising Frankenstein's performance of scientific masculine arrogance (for the purpose of denying his own feminine self), Spark shows in The Ballad that monstrosity is a social, an ethical, and more importantly a psychological category for those who threaten the community with defilement. The male characters in The Ballad, who bear the monstrous fantasy, subjugate the dignity of the female body in order to dissolve their fear of becoming too feminine in their domestic affections; unfortunately, the price for performing their intentions is blood and punishment.

The central argument of this chapter is that although monsters are those who are rejected by the community, they are also a group of subjects whose self-definition, for whatever reason, demands that they exist both inside and outside the community structure. The monstrous, referring here to the ethical errors of human consciousness, actually mixes boundaries between reality and illusion in both The Ballad and in Frankenstein. I would argue that 'ethical error', as a literary motif, shows Spark's concern for modern moral values and foregrounds the psychological and social dimensions of The Ballad.

\section{MORAL AbSENTEEISM AND GENDER ABJECTION}

As an 'Arts man', Dougal plans to work independently to 'bring vision into the lives of the workers' (16). He is told that absenteeism is a problem, but ironically, under the guise of doing research, he himself manages to do no work at all. His work becomes the making of mischief; he tells the workers to take a day off, or never to go in work on Monday mornings, instead of finding out the cause of their absenteeism. Absenteeism then goes up by eight percent. After giving troublesome 'advice', he proceeds to acquire another job doing as little work as possible with the firm of Drover Willis, also a textile manufacturer and a competitor of Meadows, Meade and Grindley. When Peckham later becomes a chaotic land of intrigue, violence and murder, Dougal escapes to Africa. He releases the inner wit in all Peckham citizens. Even though absenteeism is already a symptom of the moral disease characteristic of Peckham citizens even before Dougal's appearance, Dougal's intentional encouragement for worker absenteeism satisfies the workers' exasperation with societal hypocrisy.

Dougal acts as a catalyst which changes the actions and attentions of individual people. He declares that 'we all have a fatal flaw' (29) and plans to expose the 'flaws' of those around him:

Take the first category, Emotional. Here, for example, it is considered

immoral for a man to live with a wife who no longer appeals to him. Take

the second, Functional, in which the principal factor is class solidarity

such as, in some periods and places, has also existed amongst the

aristocracy, and of which the main manifestation these days is the trade

union movement. Three, Puritanical, of which there are several modern

variants, monetary advancement being the most prevalent gauge of the

moral life in this category. Four, Traditional, which accounts for about

one per cent of Peckham population, and which in its simple form is

Christian. (83)

These four categories of moral values illustrate the behaviour of Peckham's citizens. Malkoff defines such equivalences:

Emotional, Mr. Druce, whose life is narrow-minded; Functional, the

office typists, jealous of Miss Coverdale's special relationship to 
management; Puritanical, chiefly Dixie, who will do anything to save money, but who feels no guilt sleeping with Humphrey whenever she can. Of the traditionally moral, there are no examples. What the first moral three types have in common is their response to human beings as objects subordinate to other concerns. ${ }^{3}$

Each character lives in his world of values, and Dougal serves as a moral agent to trigger these values as they are held and performed, albeit unknowningly, by the residents of Peckham. The discovery of these prejudiced moral values, however, leads readers towards an awareness of these characters' mental illnesses; all point to 'A sense of Self without a sense of the Other, [that] can be psychologically and morally devastating'.

In fact, Malkoff's view over-classifies the stereotyped characters. The moral values associated with a locale are more or less affected by its economic development. In other words, the bourgeois bosses take advantage of their commanding right by fulfilling their sexual desires with their employees. I contend that 'Emotional' represents Mr. Druce's sexual exploitation of the female body under the condition of sex without love; 'Functional' indicates the bourgeois class supported by the trade union; 'Puritanical' represents a frugal but impudent view on sex; 'Traditional' encompasses a small population based on Christian values. The first three categories belong to the same category and signify how economic power governs social class and leads to materialism, particularly as illustrated in the objectification of the female body. All of these manifestations are the counterpart to the last one, the 'Traditional', where the belief of a person who is devoted to God's will and governed by the prescription of human love. This suggests that freedom merely comes from submission to God's will; however, Peckham's apparent freedom comes from economic pleasure and from power. A demonic character such as Dougal suggests freedom to Peckham's citizens through banal moralising and through his temptations that allow humans to rebel. Dougal brings disaster upon Peckham through a his use of dangerous freedom - ignorance, fighting, and murder.

Pictured as a possible embodiment of Satan, Dougal elicits from Peckham the desire for freedom from daily oppression and hypocrisy; hypocrisy functions as a mask and particularly evident in the novel is the masculine maltreatment or psychological rejection of the female body when men still desire to maintain the sexual relationship with their female partners. Dougal's two bosses, Mr. Druce and Mr. Willis, both adhere to a popular businessman's idea that the combination of arts and profit will, in the sight of their employees, make them better workers and more profitable businessmen. In fact, the two businessmen are afraid of being discovered in their own mammonism and are therefore audacious regarding Dougal's insinuations. Dougal feels indifferent to his girlfriend's disease while Mr. Druce treats his ex-wife (Merle) as a sexual, material object; Mr. Willis's mercilessly efficient methods concerning his female employees, together with Humphrey's flight from his wedding ceremony, illustrate a similar aversion to the female body.

Negotiating 'the Other within' (loathing the female body but in fact fearing the female power of domination), men in The Ballad seem to reduce maternity to nature, taking for granted the physical subordination of the female body. Kristeva uses the maternal body; in her view, we are always negotiating this Other within, the return of the repressed as I explained in the Introduction. The men in The Ballad are never purely subjects of their own experience, but are often products, as indicated so often by their behaviour of economic competition. While diagnosing the dynamics of oppression in Peckham's inhabitants, we may observe that male identity, which is particularly tinged with a bourgeois sense of class power, is constituted by excluding anything that overwhelms man's position as dominator, even domestic affections such as romance and sexuality. This provides the rationale behind my desire to analyse men's materialistic objectification of the female body as shown in The Ballad.

\section{A DeVil Figure as Projection Of Mental Illness}

Although the modern conscience is barely been presented in Spark's novels, the devil is far from

\footnotetext{
${ }^{3}$ Malkoff, Karl. Muriel Spark. (New York \& London: Columbia University Press, 1968), p. 24.

${ }^{4} I b i d$. p. 25.
} 
banished in her depictions of a contemporary industrialised world. Spark's devilish characters often function as providing a kind of vivisection of human psychic violence, emerging from a social tradition that advocates a lack of self-respect and a perverse pleasure in abhorring the Other, especially when it comes to the male sardonic teasing of women. Gregson suggests that the lives of Spark's characters cannot be alleviated because they are unable to transcend psychic illness, and are incapable of developing harmonious relationships with others. ${ }^{5}$ This is particularly evident in The Ballad. Spark's satirical vision underscores how human beings in contemporary society suffer from an internal violence that disturbs the precarious harmony of the Peckham microcosm. Gender issues are highlighted through fictional conversations relating to the appearance of Dougal Douglas and reach their climax in a series of accidents: Mr. Druce's murder of his mistress, Dougal's flight, and Humphrey's remarriage with Dixie. We can say that Dougal is not so much a gangster

who diabolically destroys the peace in Peckham, but that he is a figure who induces the fury of residents towards themselves and towards others.

Ostensibly, he is a Satan figure in human shape, rather than a social advisor in Mr. Druce's firm. He serves to seduce rather than to create evil. Spark presents Dougal as a seductively satanic figure in suburban surroundings; he leads the residents of Peckham to reveal their own devilish desires-some having originated in the realm of the mind only to be translated into action through betrayal, violence, and murder. Dougal is introduced into the London suburbs of factory and office; he artfully 'plumb[s] the industrial depths of Peckham' (17), revealing Peckham'sundercurrents of fraud, violence, and sadism.

It is through the dynamic interactions of Dougal, his boss, and friends that we can observe the psychic state of the gendered abject, particularly through several male characters. Humphrey favours the world of Dougal Douglas, a world in which people are urged to do what they wish to do, and he fails to recognise the extent of such dangerous freedom. Dixie, who blames Humphrey's initial defection at the altar on Dougal, exemplifies the typical eighteen-year-old small-town girl who, knowing that she is low on the scale of social hierarchy, tries to rise in status through misery and hard work in order to save enough money for a fine house. Humphrey, her lover, represents the average good young man intrigued by the charm and freedom of Dougal, who brings the excitement of rebellion to his dull life. Although he returns for the wedding later, his rebellious desire to refuse marriage and his defensive remarks for Dougal's world of freedom indicates in men the fear of women and then the vindication of this fear. If Dixie fulfils her wish and saves enough money for a fine house, she will then represent a very domestic economic power. Humphrey's fear that his bride may grasp such the reality of such economic empowerment makes the readers associate Dougal's fear with his earlier comment about leaving the 'wedded wife' and putting the 'bacon' aside. The capitalist bourgeois ideal translates the woman's domestic position into a functional, rather than an affectionate, role; the gendered abject is equated with materiality.

In The Ballad, several material devices are used to screen what the characters say to each other from the rest of the listening word. When Merle, the head of the typist pool, and her employer, Mr. Druce, dine together at her apartment, their desultory conversation takes place as '[an] accompaniment to a documentary travel film' (52). During another dinner, he turns off the television: 'Bad for the digestion while you're eating,' he says, but the two do not speak during the entire meal. Their romance is frighteningly nothing more than routine. After Mr. Druce showers, he puts a 'wet irritable hand round the bedroom door' (54). Though she does not listen when he speaks, Merle understands why his hand is 'irritable', and she wordlessly hands him a towel. It is truly ironic that when Mr. Druce later murders Merle by stabbing her with a corkscrew, he does so above the roar of the television. Kristeva suggests that the operations of identification and differentiation are necessary for the signification of identity is prefigured in a subject's incorporations and expulsions of food in particular. ${ }^{6}$ The food here seems incorporated through their mutually taciturn behaviour. Mr. Druce's sexuality is fulfilled in a series of regular but ignorant acts: dining, watching, showering, and ironically murdering when he escapes a necessary conversation with Merle. This series of actions replaces the fear of affection, because frank confrontation threatens to infringe upon the subject's border.

\footnotetext{
${ }^{5}$ Gregson, Ian. 'Muriel Spark's Caricatural Effects'. Essays in Criticism. 55:1 (January 2005): 1-16. p. 5.

${ }^{6}$ See Kristeva'sPowers of Horror (1982), pp. 75-76, and also Introduction of this thesis, pp.12-13.
} 
With Mrs. Druce, Mr. Druce has no dialogue at all. He tells Dougal that the two have not spoken for nearly five years. One day during lunch, she suddenly says, 'Quack, quack', then 'quack, quack', and again 'quack, quack'. Her hand is opening and shutting like a duck's bill as she tells her husband: 'That's how you go quacking on'. 'From that day to this', Mr. Druce tells Dougal, 'I've never opened my mouth to her'. Dougal asks how they communicate. Mr. Druce replies, 'Write notes. Do you call that a marriage?' (66). Mr. Druce's hatred towards Merle is a fabricated mask disguising his long-term horror of his wife. Spark leaves a great deal of imaginative space here-the duck-like wife might, to Mr. Druce's eye, be a fake figure. His fear of communication with woman parallels the closure of his emotions and thoughts to his mistress, Merle.

Mr. Druce's indifference out of his self-defense, even in his retrieved romance with his ex-wife, is somehow affected by Dougal's friendly attitude. Every time Dougal calls his ex-sweetheart Jinny, she tells him that she has to hang up because she has something cooking on the stove. Jinny always promises to return his call, even though Dougal is well aware that she does not even know his phone number. As an artist, Dougal's detachment evokes the personality of an impersonal, totally objective outsider. This lacking personality is reflected through a lack of emotional commitment, particularly in the relationship with his girl friend. When Jinny falls sick and is hospitalised, Dougal avoids her, pleading his flaw - his inability to stand any sickness - as an excuse. Predictably, this refusal costs Dougal his girl: Jinny withdraws into bitter silence.

Besides the gender problem of emotional commitment, incompatibility is also an issue that exists between the two sexes. It is understood that 'any of the girls might break off in the middle of a sentence, should a young man approach her ....'The actual invitation to dance, however, is 'mostly delivered by gesture' (58). All rhetorical questions here veil a gender problem of incompatibility. Apparently convinced that man's communication problems can best be solved by machines, Dougal advises Merle, 'Type it out and forget your troubles. It's a nice typewriter. You'll find the paper on the table'. As she types, he lies back on his bed, remarking, 'There is no more beautiful sight than to see a fine woman bashing away at a typewriter' (129). The sardonic compliment connotes a deadening mental illness. Female beauty again is objectified into something like a working machine-like a typewriter - and the speaking female subjects seem to be praised without either words or smiles.

Quite different from the other helplessly manipulated female characters, one of Dougal's aids in his 'human research', Nelly Mahone, remains, unlike many of the other character, essentially unchanged by the town's strange visitor. Nelly's stability probably results from the fact that she readily falls outwith the realms of convention and respectability. She comments on Dougal's mischievous 'advice' saying that 'It's all clean dirt' (94). This description can apply to her moral nature as well. Even though Nelly is seen as a village idiot, she also serves as the reminder of a spiritual order far removed from the petty concerns of so many other characters. Dressed in rags, she lurks outside the pubs, screaming out passages from the Bible and praising 'the Lord, almighty and eternal, wonderful in the dispensation of all his works' (26). Spark frequently includes this oxymoronic character, a wise fool, as her spokesperson. Here it is Nelly Mahone, a half-mad street evangelist who lives in a messy, uninviting hovel with 'clean dirt'. Nelly says that

Six things ... the Lord hateth, and the seventh his soul detesteth ... a

lying tongue ... a heart that deviseth wicked plots ... a deceitful

witness . . . and [among others] him that soweth discord among brethren.

(107)

If the figure of Dougal represents a 'lying tongue' which substantially fights with God's moral law, Nelly's ignorance of Dougal's human research paradoxically shows itself a 'deceitful witness' to Dougal's immoral acts.

After Nelly becomes suspicious of Dougal and refuses the money he wants to give her for spying for him, he tells her that he had a pair of horns like a goat when he was born. She says, "Holy Mary, let me out of here. I don't know whether I'm coming or going with you' (114). Dougal's 'horn story' incites Nelly's fearful response to temptation. Later, when he comes out of a film, Nelly stands outside declaring words that suit Dougal exactly: 'The words of the double-tongued are as if they were harmless, but they reach even to the inner part of the bowels' (132). As he passes her, she spits on the sidewalk. The representation of Nelly Mahone underscores the moral discord that characterises 
Dougal as well as Peckham. In Spark's Ballad, readers are often led to explore concord through an experience of discord, and to honourinnocence through an experience of the devil. The Ballad's disordered world of alienated misfits carries a grim motif of invented moral reality.

\section{The Symbolic Meaning Of The Murder And The Evasion}

The climax of the story, Mr. Druce's murder and Dougal's flight, symbolises the ultimate exertion of a profound fury and the ensuing punishment rendered upon the conscience. Dougal, as Christianson suggests, is a particularly Scottish devil, and remains a mythical figure of the ballad within the novel; utilising the ballad's style and themes, Spark's The Ballad is filled with 'repetitions, shifts in time, juxtapositions of the supernatural and the everyday, and sudden death'. ${ }^{7}$ The devilish character Dougal might be Scottish, with his cunning stylish play between illusion and reality, but the theme is a reversal of the punished devil as he appears in traditional ballads. The devil ultimately wins over those who defy him, because the more they defy him, the more difficult he can get himself rid of the devil. This becomes a psychological problem such that the inner devil cannot be obliterated until it is confronted. The betrayal and sudden death of the devil's followers, rather than of the devil, at the end of the novel presents the style of balladic heroes in reverse to the traditional ballad form.

The most 'successfully' triggered inner devil is manifested by Dougal through his employer, Mr. Druce. Mr. Druce shows a deeply-rooted psychological complex between love and hatred. The exertion of the gendered abject is finally performed by Mr. Druce, but Dougal, the indirect cause of the murder, evades the crime.

Mr. Druce first becomes obsessed with Dougal and pursues him in lover-like fashion. Convinced that his mistress Merle Coverdale is in league with Dougal (she has been typing an autobiography for him) and really hating her (as shown by his determination to pinch, bite, and bruise during the act of lovemaking), he stabs her nine times in the neck with a corkscrew and kills her; he then puts on his hat and goes home to his wife. This ultimate gender maltreatment counteracts the very opening lines of The Ballad to Humphrey Place's returning visit to Dixie:

'Get away from here, you dirty swine', she said.

'There's a dirty swine in every man', said he.

'Showing your face round here again', she said.

'Now, Mavis, now, Mavis', he said.

The return visit at the very beginning of the novel shows the male repenting for the betrayal of his bride. This contradicts Mr. Druce's furious murder at the end of the novel. Mr. Druce's murder, which serves as Spark's final rebuke of a dumb conscious businessman, forms an opposite point to Humphrey's awakening from his previous transgression at the wedding. In Tales of Love, Kristeva suggests that misplaced abjection is one cause of women's oppression. ${ }^{8}$ This misplaced abjection accounts for woman's degradation within patriarchal cultures. Humphrey's confession that there exists 'a dirty swine in every man', not only excuses his flight from the wedding ceremony, but also reveals his recognition that the misplaced abjection is elsewhere made manifest.

Spark mocks Dougal's indifference to all that has happened around him in the novel, except Humphrey's awakening from his improper flight from his wedding. When a policeman repeats that he has discovered a body bearing a scrap of paper with her last name on it, Miss Frierne denies that the corpse is her brother: she doesn't want to pay for his funeral. Imitating a dead man by lolling his head back and making his jaw rigid, Dougal grimly proceeds to send his landlady into a state of hysterics. When Miss Frierne herself soon approaches death by having a stroke, Dougal's moral responsibility becomes even clearer. After the doctor asks him if 'she has got any relatives', he utters a simple ' No'

\footnotetext{
${ }^{7}$ Christianson indicates that Spark wrote Ballad within Scottish traditions as seen in the ballads, in Hogg's Confessions of a Justified Sinner and Stevenson's Dr Jekyll and Mr Hyde. Death, betrayal, and duality are the major motifs. See, Christianson, Aileen. 'Muriel Spark and Candia McWilliam: Continuities'. Contemporary Scottish Women Writers. Eds. Aileen Christianson and Alison Lumsden. (Edinburgh: Edinburgh University Press Ltd, 2000), pp. 95-110 (95). And, Christianson, 'Certainty and Unease in Muriel Spark's The Ballad of Peckham Rye'. Scottish Women's Fiction: 1920s to 1960s: Journeys into Being. Eds. Carol Anderson and Aileen Christianson. (East Lothian: Tuckwell Press Ltd, 2000), pp. 134-146 (136).

${ }^{8}$ Kristeva, Julia. Tales of Love. Trans. Leon S. Roudiez. (New York: Columbia University Press, 1987), p. 374.
} 
(137) — just as she had recently done when asked if the dead man was her brother. Miss Frierne's sick body has been dismissed as a corpse; her corpse ultimately becomes Dougal's object of abjection.

Dougal's most obvious ties are to the devil; however, in this capacity, he is never a fully convincing figure. Dougal's personal descriptions are as varied as the perceptions of him that are held by various townspeople. At different times, he both concedes to being and denies being a devil. He is capable of an ambivalent posturing: '. . . posed like an angel on a grave' (30). Dougal also claims powers of exorcism, which, he insists, do not contradict his claim to be devil as well. At yet another time, he is no devil but admittedly one of the wicked spirits for 'the ruin[ation] of souls' (77). The true nature of Dougal's identity cannot be verified. His protean identity becomes his primary role in Peckham and gains mythic proportions in the book, proportions that surpass those of ordinary mortals. Dougal, the Satan character, becomes an author who achieves success through 'cocked-eyed' books. Spark's few comments on fiction writers in this novel are revealing.

The autobiography of Miss Cheeseman, as written by Dougal, contains lies that are themselves fictions. A devil who writes 'cock-eyed' books is a successful author. Dougal, walking through the tunnel on his way out of town, juggles six shinbones from the excavations. He is as cynically playful with the psychological relics of Peckham's demoralised citizens as he is with the bones of the longdead nuns. Most of the people to whom he offers 'vision' are about as inert as the excavated skeletons and they do not resist him. He operates just like a magnetic, attracting his homogeneous followers. The flaw of Peckham's citizens is a fear of the proximity of illness, but they cannot confront this flaw on their own. Although Spark maintains a certain emotional distance from her characters, there is a great deal of subtle compassion implied in The Ballad. Inert and petty though the concerns of the Peckham community might be, the moral fragility of people under Dougal's manipulation is quite threatening. Evil is finally driven away by the honest presence of an abject mental state (disease and frailty) and Dougal's deceiving vision, his eye, is battered with a bone after he contemptuously juggles the bones of Peckham.

\section{Giving Life To Darkness, The Monstrous And The Human}

Spark has discussed the novelty and success of Frankenstein as a fictional genre, praising its horror element to a most sinister degree. ${ }^{9}$ However, she also criticizes Frankenstein's many faults, such as the weak chain, the poverty of characterisation, the rigid timing of the plot. ${ }^{10}$ She seems to agree that the reproaching voice about punishment results from mankind's inner evil, but disagrees about the way those characterisations of evil are being manifested: they are too realistic in appearance and too terrifying. Regarding the nature of the inner evil shown in Frankenstein, Harold Bloom remarks that the major theme of Mary Shelley's Frankenstein is a reaction against Prometheanism, for Prometheanism overvalues the romantic spirit in consciousness despite all costs. ${ }^{11} \mathrm{He}$ considers that just as Prometheus deserves punishment from God for stealing the fire, so Frankenstein deserves the monster's conscientious punishment for his disobedience towards God's rule. In other words, he disdains that kind of romantic spirit which accuses the divine benevolence of a vindicated murder. I propose that if Spark also praises the reasonable punishment of mankind's internal evil, she has then successfully revised the realistic emergence of the monster in the Frankenstein monster as a more humanised devil character in people's lives. Spark encourages a subversive romantic spirit to disturb the routine of veiled hypocrisy. She believes that the real romantic spirit should carry with it humanity, and she urges people to confront those things by which they are oppressed and which they immorally want to suppress. I believe that it is through her assertion of a realistic description of mankind's devilish motives (in the psychological construction of a self borderline) that Spark tends to make against the nineteenth-century realistic narration of an external materially-mixed monster who leads humans to substantial destruction in Frankenstein. The Ballad deviates from the fantasy / reality of Frankenstein because it foregrounds a belief that psychological motives create our perceived reality, rather than that the empirical monsters generate our torturing trauma.

Like some of the greatest verse-ballads, Spark's prose Ballad has a supernatural participant. After

\footnotetext{
${ }^{9}$ See Spark, Muriel. 'Frankenstein'. Mary Shelley. Ed. Harold Bloom. Modern Critical Views. (New York: Chelsea House Publishers, 1985), pp. 11-30.

${ }^{10}$ Ibid., pp. 24-25

${ }^{11}$ Ibid., Bloom, Harold. 'Introduction'. pp. 1-10(8).
} 
discussing the devil, Dougal Douglas asks Humphrey Place to feel the little bumps on his head and explains that he had them removed by a plastic surgeon who, 'did an operation and took away the two horns' (77). In closing, the novel restates the ballad motif by indicating that the world as we see it is not all there is. Humphrey is aware of Peckham Rye 'for an instant looking like a cloud of green and gold, the people seeming to ride upon it, as you might say there was another world than this' (143). The evil disturbance at the very beginning and the otherworldly tranquility at the very ending of the novel, foreground the central motif of life and death are evil as they prevail upon the external and internal. This life/death motif, so symbolical of reality/fantasy, motivates me to attempt a new approach to Spark's text in The Ballad.

In nineteenth-century realism, narrativity and domesticity stand in opposition, each coming into being only at the other's expense. ${ }^{12}$ Such opposition is an organising principle in The Ballad. What remains different, however, is that nineteenth-century realism attributes credible moral judgments to the fictional narrator's voice which might represent the author's belief (such as Robert Walton's traumatic witness and frank confession in Frankenstein), whereas Spark's realistic move in The Ballad provides the ironic effect of the characters' moral values in their dialogues directly to the readers.

Dougal in The Ballad encourages the workers of Peckham to absent themselves from their factory so as to discover a spiritual alternative to their workplace. His suggestion that workers take Monday off as a holiday (39), ironically encourages a running joke about the morality or immorality of such 'absenteeism' (84). He exposes the emptiness of those he encounters and appears ironically to be more rounded than his ostensibly realistic counterparts. Although what he offers to the workers of Peckham are only pieces of clichéd advice, his diabolic phrases offer great insight. He is constructed by the kind of phrases that he is collecting for use in his ghost-written autobiography of Miss Cheeseman, a retired actress. When the electrician Trevor Lomas steals Dougal's notebook, he finds phrases like 'I thrilled to his touch', 'I reveled in my first tragic part', and 'We were living a lie' (91). Dougal has picked up some of these lines from his acquaintances in Peckham, but does not, himself, have a significantly contrasting idiom. He offers such phrases to everyone. He is trying to rewrite a glamorised story of each person's life - not just Miss Cheeseman's - and to then sell each person that story. Dougal seems to have written a book (he claims to be psychic) like the one Mr. Druce keeps in his desk, Marital Relational Psychology. Even before Mr. Druce shows Dougal the book, Dougal has spoken about such concept, imitating a marriage counselor, 'There is some question of incompatibility, I should say' (65). He then continues with an ego-inflating jargon: 'You have a nature at once deep and sensitive, Mr. Druce' (65). He does not uncover deep truths about people but his phrase has an ironic effect on his readers because we know that Mr. Druce's egoism carries masculine pride.

Shelley's male characters experience masculinity as an urgent imperative that originates at the core of their innermost selves. As Walton indicates in the second letter to his sister, however, its exact source and purpose remain obscure:

There is something at work in my soul, which I do not understand ...

there is a love for the marvelous, a belief in the marvelous, interwined in

all my projects, which hurries me out of the common pathways of men,

even to the wild sea and unvisited regions I am about to explore.

(Frankenstein, 9)

We can also discern this desire to enslave (to enslave internal evil and blindness towards the psychic real) through Mr. Druce in The Ballad. A deceptive use of words abounds in The Ballad, such as in Dougal's interview with Mr. Druce, during which time 'create' has more than one proper interpretation. Mr. Druce has no idea how creative Dougal can really be in shifting appearances; the post created for him in turn is a creative one for Dougal, just as an impact of the monster to Victor in Frankenstein. Under the guise of conducting a research, Dougal in The Ballad and Victor in Frankenstein both misuse their power so as to deceive the people around them into thinking that they are really valuable consultants on workplace issues.

\footnotetext{
${ }^{12}$ Morris, Pam. Realism. The New Critical Idiom. (London and New York: Routledge, 2003), p. 86.
} 
The monster scares Victor because he looks degenerate yet human; manufactured yet alive; mechanistic yet sexual-in the same way that Dougal threatens Mr. Druce because all he sounds transgressive yet alluring. In abandoning the embodied form of his work, however, Frankenstein fosters a horror of the body, a fear of degeneracy and a disgust at the disorder he has introduced within what he once thought to be a neat and perfectible scientific system. Once again, his compulsion to push knowledge beyond certain boundaries produces, in his eyes, 'a deformed and abortive creation' (36). Victor feels disgust for 'the wretch-the miserable monster' because it represents his unorthodox desires, his scientific heresy, his disassociation from the nuclear family, and his belief in the coincidence of purity and beauty. Victor turns his dismay into a horror of the beast of social disorder and makes his creature stand for all the elements that threaten his status as a middle-class male. 'The beauty of the dream vanished', says Victor, 'and breathless horror and disgust filled my heart' (57). In naming his experiment 'monster', then, Victor hints at the ideological dangers of a theory of evolution. By displacing God with science, belief with technology, a 'paradise lost' with a body regained, Victor is struck by the fear of God and Nature and by an even greater fear of the social anarchy threatened by God's absence. In an attempt to immediately reinstitute a hierarchy and a social order that threatens to disappear with the Chain of Being, Victor reviles his creature as deformed, impure, inhuman; he calls it 'the malice of the fiend' (99). In refusing to recognise the creature as human, Victor both limits the definition of 'human' and refuses to recognise the part of humanity that is monstrous by placing distance and difference between himself and his 'vampire'.

For Mr. Druce, Dougal is the vampire who attracts the pleasure of egoism but who demoralises Mr. Druce and threatens his normal existence. What deserves our attention is that while the inhuman fantasy is well-endowed by mankind, men cannot escape from the disastrous. George Levine indicates the relationship between reality and fantasy in Frankenstein:

We know that the Monster is a double of Victor himself, and that as he acts out his satanic impulses he is acting out another aspect of Victor's creation of him. God, however, cannot be a rebel; nor can he be Adam or Satan's "double". He cannot be complicit in his creature's weaknesses, cannot be destroyed by what he creates. The whole narrative of

Frankenstein is, indeed, acted out in the absence of God. The grand gestures of Frankenstein may suggest a world of fantasy that has acquired a profound escapist appeal in modern culture, but they take place in a framework that necessarily makes an ironic commentary on them, even while our sympathies are drawn to dreams of the more than human the narrative will not allow. ${ }^{13}$

Operating out of such assumptions, Spark uses literary conventions of the double (Dougal and Mr. Druce in The Ballad, the monster and Victor, Victor and Walton in Frankenstein) to build our expectations and to involve us therein before she overturns those expectations by including realistic descriptions within larger realities in The Ballad. The problem is one of discovering the unique nature of the worker's values in Peckham and of suspending various beliefs. In other words, it is not merely the individual's psychic disease that Spark wants to reveal, but the whole society's disease that she wants to criticise. It is this double-edged mocking and self-mocking that distinguishes the satire of The Ballad.

\section{The Critique Of A MATERialistic Society}

I want to focus on narrative structure and linguistic satire in The Ballad and in Frankenstein in order to mark the injustice of social institutions as the crucial demon and as the central motif of The Ballad; this injustice is widely evident in the alienation from domestic affections and in the unconscious male

\footnotetext{
${ }^{13}$ Levine, George. 'The Ambiguous Heritage of Frankenstein'. The Endurance of Frankenstein: essays on Mary Shelley's novel. Eds. George Levine and U. C. Knoepflmacher. (Berkeley, Los Angeles, London: University of California Press, 1979 [1974]), pp. 3-30 (7).
} 
fear of the feminine. First of all the narrative structure colours the parallel between these two novels. Although the monster's narrative is contained within the narratives of Walton and Victor, he does tell the story of his exclusion from the community, of his loneliness, and of his perception of his own criminality. The monster's narrative, in its break with Gothic convention, complicates the politics of monstrosity and draws attention to the fact that monsters are made, not born, and can therefore be perceived in ideological terms. In The Ballad, the time scheme of the plot is ruptured into unchronological order such that conversations among characters leave much space for critical thinking among readers.

David Punter in The Literature of Terror defines Frankenstein and the Gothic as 'form[s] of response to the emergence of a class-dominated capitalist economy'. ${ }^{14}$ In his reading of the novel, Punter emphasises the theme of the irresponsible scientist who is committed only to scientific truth and who is intent upon eradicating 'the ugly, the unpredictable and the disruptive'. ${ }^{15}$ Punter attempts to ground his study in history and asks why 'symbols of injustice and malevolent fate should be conjured up at a particular historical period'. ${ }^{16}$ The answer, he suggests, has everything to do with the emergence of bourgeois culture and with the struggle of that group against aristocratic corruption and the threat of the proletariat. It is this institutional injustice that induces human disease; this, I will argue, can be discerned in The Ballad as well.

\section{Alienation In Domestic AfFections}

As I mentioned earlier, the boundary between fantasy and reality is often blurred by the undertones of the narrative's uncertainty. Sparker's intention in obscuring characters' idiomatic conversations shows her largest attempt to challenge what we perceive as the reality. Spark uses the 'as if' to create confusion as to what is actual (with the characters' interactions) and what is narrative truth (for the readers to decipher the character's psychology):

As he opened the street door, young Leslie slid in as if from some

concealment. . .

Elaine started to sing in the same tone as her screaming, joylessly, and as

if in continuation of it.

Did it sound as if I was carrying her upstairs?

Collie blew out his smoke as if it were slow poison. $(36,47,48,92)$

The ('as if') uncertainty of language opens up the possibilities of the realist observation. Leslie is occupied with the shady dealings; Elaine only appears to sing; Humphrey is carrying Dixie upstairs; and Collie's cigarettes are slow poison. But are these truly happening or just actions that cover these characters' momentary thoughts? By questioning the narrative 'truth', Spark cautions the readers not to judge too quickly. The most evident is the (apparently but ambiguously) devilish character, Dougal Douglas:

Dougal came in just then, and walked with his springy step all up the

long open-plan office, bobbling as he walked as if the plastic inlay

flooring was a certain green and paradisal turf. (97-98)

$\mathrm{He}$ is associated with the devil throughout the novel but is also ironically strengthened here by the 'as if'. With his mischievous but malicious advice, he looks happy 'as if' walking in the paradise. By contrast, with decent behaviours following daily routines, the Peckham's residents bear usurping and transgressive desires.

In The Ballad, Dougal offers a false initiation, a false holiday - when on the 'holiday' of absenteeism, to relax is to alienate oneself from human affections. On the evening of his Monday off, Mr. Druce and his mistress Coverdale routinely make love. Dixie rebukes Humphrey's effort to act in a similar

\footnotetext{
${ }^{14}$ Punter, David. The Literature of Terror: a history of gothic fictions from 1765 to the present day. (London and New York: Longmans, 1980), p. 128.

${ }^{15}$ Ibid. p. 125.

${ }^{16}$ Ibid. p. 127.
} 
fashion. Dougal play-acts in the ballroom, rowing, fishing, dancing, all with a trashcan lid as his only prop. It is easy for Dougal to be the devil's advocate in the love affair between Humphrey and Dixie, she but 'seventeen, [and the] daughter of the first G. I. Bride to have departed from Peckham and returned ...' (10). Dixie pennypinches her way through a meager existence, squirreling away every shilling for a 'spin dryer' and a bungalow; she doles out sex as ungenerously as she spends moneyHumphrey spends most of the novel trying to unbutton her coat so they can make love in a closet. Dixie is left at the church altar by Humphrey with words that have been suggested to him subliminally by Dougal:

The vicar said to Humphrey, 'Wilt thou have this woman to thy wedded wife?'

'No', Humphrey said, 'to be quite frank, I won't'. (8)

This sardonic view of emotion is typical of Spark. There is no passion in sex and in another so-called romantic relationship - this one dealing with a murder - there is no passion even in killing. Mr. Druce, who spends his Saturday afternoons sleeping with his secretary, Merle Coverdale, thirty-seven and head of the typing pool at Meadows Meade, is as appealing as the brussel sprouts which Merle slowly stews for him.

[They] ... took off their clothes in a steady rhythm. Merle took off her cardigan and Mr. Druce took off his coat. Merle went to the wardrobe and brought out a green quilted silk dressing-gown. . . . Merle took off her blouse and Mr. Druce his waistcoat. Merle put the dressing-gown over her shoulders and, concealed by it, took off the rest of her clothes, with modest gestures ... (53-54)

Not only is his violence stupid, it is also studied and deliberate.

The corkscrew lay on the sideboard. He lifted an end, let it drop, lifted it, let it drop ... [Then] he came towards her with the corkscrew and stabbed it into her long neck nine times, and killed her. Then he took his hat and went home to his wife. (136)

There is no love in the gender relationship, even in sex. Mr. Druce's fatal flaw-deliberate violencebecomes Spark's sharpest irony in her ridicule of love affairs.

His internal split represents a case of Kristevan abjection as produced by 'what disturbs identity, system, order. What does not respect borders, positions, rules. The in-between, the ambiguous, the composite'. ${ }^{17}$ Significantly, Elizabeth Grosz defines abjection as 'the expression of a contradictory self-conception, one in which the subject is unable to reconcile its (imaginary and fragmented) experience of itself with its idealised image' ${ }^{18}$ In his excitement over his discovery, Frankenstein declares:

Life and death appeared to me ideal bounds, which I should first break through, and pour a torrent of light into our dark world. A new species would bless me as its creator and source; many happy and excellent natures would owe their being to me. (52)

His rejection of his creation stems from a realisation that his creation is neither a purified nor a radically different form of humanity. Rather, the monster is a mottled man, a sutured patchwork of

\footnotetext{
${ }^{17}$ Kristeva, Julia. Powers of Horror: an essay on Abjection. Trans. Leon S. Roudiez. (New York: Columbia University Press, 1982), p. 4.

${ }^{18}$ Grosz, Elizabeth. Sexual Subversions: Three French Feminists. (Australia: Allen \& Unwin Pty Lds, 1989), p. 94.
} 
mixed skin and blood, a very spectre of mis-composite that was to prey upon all nineteenth century dreams of purity.

\section{The Escape From The Female Love}

In the last sentence of The Ballad is there a brief illumination of brighter humanity: driving away with Dixie after their wedding, Humphrey observes the Rye community to be peaceful. Humphrey's brief vision has no unifying effect. There is no indication of how Humphrey feels when he sees the bright green Rye. The citizens of Rye are hardly visionaries, and Dougal's parodic posing as an awakener of souls results only in disorder and not in harmonious illuminations. The feminist concern is uttered; the male desire to flee from the wedding becomes symbolical of domestic affections and of the internal union between the masculine and feminine in the lives of men.

The past years of feminist criticism on Mary Shelley's Frankenstein have established the novel as a text concerned with pregnancy, child-birth and parenthood. In her much quoted essay, 'Female Gothic', Ellen Moers laid the foundation for reading Frankenstein as 'a woman's mythmaking on the subject of birth'. ${ }^{19}$ In a recent study of Mary Shelley's life and works, Anne Mellor suggests: 'One reason Mary Shelley's story reverberates so strongly is because it articulates, perhaps for the first time in Western literature, the most powerfully felt anxieties of pregnancy' ${ }^{20}$ Mellor goes on to define the monster as a product of the nuclear family's failure to mother its children, and she sees Frankenstein as a monomaniacal scientist who wants to create a world without women. She writes that, 'by stealing the female's control over reproduction, Frankenstein has eliminated the female's primary biological function and source of cultural power'. ${ }^{21}$ By insisting that women's 'cultural power' lies in childbirth Mellor, and other critics, simply tie the knot between femininity and maternity, between the female and nature; they reproduce a static relationship between masculinity and a system of dominance.

Reading Frankenstein as a narrative preoccupied with the means by which monstrosity is identified with the foreign, the alien, the ugly, I contend that the monster needs not only represent the negative impact from humans' transgressive desires but also represent 'woman' or the horrors of maternity. If the monster is Frankenstein's child, he is also a slave forged out of scientific discovery and a world lacking the ability to nurture. If the relationship between the scientist and his creation suggests social bondage, it is also tinged with the repulsion that nineteenth century science exhibited towards the idea of purity. The monster, in other words, merges class, race and gender-based anxieties, opposing Otherness to the unity and sanctuary of family. The monster, in this sense, may be identified with the threat of the feminine, the threat, that is, of difference, but also of exclusion from the family and all human community. Frankenstein's monster terrifies his creator and eventually suffers rejection because he represents the combination of all those elements that threaten the hegemony of bourgeois culture.

Caroline, Elizabeth and Justine are joined to one another in a kind of sacrificial circle. Caroline dies nursing Elizabeth back to health, and Justine dies for a crime for which Elizabeth feels at least partly responsible. The same monster that commits the crime for which Justine hangs finally kills Elizabeth. Furthermore, the material evidence that finally convicts Justine is a cameo of Caroline that the boy William wears around his neck. Elizabeth, Justine, and Caroline are interchangeable within a circuit of patriarchal justice. This circuit shields Victor from the consequences of his crime. It is not simply a faculty justice system that allows the women to be punished in Victor's stead - it is the family system itself. This system enforces separate spheres and enables Victor to keep the secret of his scientific endeavours and to bind the woman to a kind a half-life within the home. The sacrificial circle is a construction of the bourgeois family and is not merely the result of a miscarriage of justice.

This satirical tone of the bourgeois family never disappears in The Ballad. Humprey's wedding at the end of the novel, together with Mr. Druce's murder of Merle, designs Spark's satire of the bourgeois family. As Dixie says after her marriage to Humphrey has finally taken place: "II feel as if I've been twenty years married instead of two hours" (143). Dougal seems the cause of a telescoping and

19 Mores, Ellen. 'Female Gothic' in The Endurance of Frankenstein. Eds. George Levine and U. C. Knoepflmacher. (Los Angeles: California UP, 1979), pp. 77-87 (81).

${ }^{20}$ Mellor, Anne. Mary Shelley: her life, her fiction, her monsters. (New York: Routledge, 1988), p. 36.

${ }^{21}$ Ibid., p. 115. 
intensification of experience in Peckham. Its people have touched and felt the supernatural and been made a part of some design or plot they cannot apprehend. Theirs is now a mythical reality, the sort which lends itself not to factual record but to a ballad of hazy detail. Humphrey attests in the final scene of the novel to the real legacy of Dougal - a 'vision' that changes the very place he knows all too well. As he and his new wife,

drove swiftly past the Rye, he saw children playing there and the women coming home from work with their shopping-bags, the Rye for an instant looking like a cloud of green and gold, the people seeming to ride upon it, as you might say there was another world than this. (143)

This domestic tranquility stands in opposition to the bloody murder of Merle by Mr. Druce. While Dixie survives the communal injustice of the wedding, Merle falls prey to an institutional injustice: consumptive sex.

We may also observe gender injustice in Frankenstein. After Justine hangs, Elizabeth relinquishes her sentimentalised view of the world and of the operation of justice. She says:

When I reflect ... on the miserable death of Justine Moritz, I no longer

see the world and its works as they before appeared to me. Before, I

looked upon the accounts of vice and injustice, that I read in books or

heard from others, as tales of ancient days or imaginary evils; at least

they were remote, and more familiar to reason that to imagination; but

now misery has come home and men appear to me as monsters thirsting

for each other's blood.

Separate spheres suggest a naturalisation of gender roles, implying an easy division of human attributes into masculine and feminine, as well as the protection of the domestic space from the crimes of the outside world. The Gothic form narrates the breakdown of all such easy divisions and remarks upon the chaos that results. Elizabeth finds that the death of Justine for the murder of William brings misery home. When this happens, the family is soon violated by a monster within, by evils that translate the realm of fiction into fact. Vice is no longer a narrative taken from history; injustice infiltrates morality. The erosion of those boundaries that form her world leads Elizabeth to conclude that men now all appear as monsters and that she can no longer make distinctions between the two. The strict morality of bourgeois respectability demands that the heroine make proper distinctions if she is to remain pure; when difference breaks down, morality ceases to function and the pure woman faces only death or dishonor. In this respect, the Gothic ruptures respectability only to restore it; the comprehension of injustice, here attributed to Elizabeth, at least suggests at least that knowledge precedes death, and, however briefly, that social awareness replaces innocence.

The rate of symbolic exchange, then, between monster and woman in Frankenstein, suggests that gender circulates within a matrix of class and race relations. The female body may represent abhorrent sexuality but it also threatens to reproduce monstrosity in a 'race of devils'. Woman's place in bourgeois culture is defined in contra-distinction to monsters that know and can distinguish men from monsters. Victor never learns this lesson. He dies still enjoining Walton's crewmembers to seek glory and holding out the possibility that another may succeed where he himself has failed. Enmeshed in a value system that the novel as a whole has subtly painted as troubling, Victor cannot recognize the claims of a community that draws Walton's crew back to England. In the end, the crewmembers are the only individuals to benefit from their endeavors. They return safely to their families, having accomplished what they set out to do: Walton's ship makes it to the pole and back again. Victor, on the other hand, spends his life fruitlessly and produces nothing of benefit either for himself or his society. The sterility of his efforts passes a final, damning judgment on the monomaniacal quest for glory that initially drives him to disdain productive labour, to turn away from community, and to create a creature that he cannot nurture. This is similar to the way in which Dougal fails to take responsibility for Mr. Druce's murder of Merle. 
Other survivors of the devastating events in these two novels are also marked for life by their contact (direct or indirect) with Dougal in The Ballad and with Victor in Frankenstein. We lose sight of Humphrey after Mr. Druce's murder, and Trevor after his fight with Dougal at the ball. In Frankenstein, we also lose sight of the De Laceys after they flee from the creature. We do know, however, that their lives are ever-altered by the encounter. The De Laceys survive, but carry deep scars with them into the future. Another scarred survivor is Victor's younger brother Ernest, whom Victor never mentions after the death of their father. In fact, Victor's claim that his entire family is destroyed is untrue: the family revives into the future by this forgotten younger brother. A reader might wonder what kind of a future this brother will have, however, orphaned and deserted as he is by Victor. Victor is so driven by his monomania that he overlooks the effects that his actions will have upon anybody but himself.

The point here is that tragedy is not a private affair: the fall of one individual leads to the decimation of many. The survivors (Humphrey in The Ballad; the elder Clerval, the De Laceys, Ernest Frankenstein, even the crewmembers of Walton's ship and the sister to whom he writes in Frankenstein) may initially seem more fortunate than those who die because of man's folly (Mr. Druce's murder of Mere in The Ballad; Alphonse, Elizabeth, William, Justine, Henry Clerval, and Victor himself in Frankenstein). Yet, much like those in Frankenstein, ultimately all characters in The Ballad fall victim to disease, to the disease of solipsism and prejudice that is entrenched within and is perpetuated by the strange system of human society that the novel lays bare for scrutiny.

\section{CONCLUSION}

Like most devil figures, Dougal has a physical deformity and makes much of his one crooked shoulder. Spark is a perceptive student of human frailty, however, and she subtly points out how his grotesque form makes him more and not less attractive to the citizens of Peckham. Evil is always attractive in Muriel Spark's novels because it offers an alternative to the mundane routine of existence, particularly to the mind-deadening that occurs in this milieu of typing pools and factory assembly lines. The disrupted daily routine of typing pools that Dougal makes obviously causes less serious trouble than Mr. Druce's murder. We know at the end of the novel that the real evil is the dullness of Peckham Rye. Dougal, whose function here is to jar the intellectually and spiritually slothful from their well-defined ruts, forces each character, in varying degrees, to re-assess the known. He serves as a force for change even though the results are rarely beneficial. From this perspective, we may say that Dougal is a fallen angel, destroying the abnormal before construction.

Massie suggests that 'Dougal is the element in the psyche that modern industrial society attempts to stifle and deny'. ${ }^{22}$ Dougal's presence in Peckham gradually exposes injured morale: his 'human research' consists largely in convincing people that they are the tragic victims of life and are therefore entitled to take casual revenge on others. This immoral sense, though seemingly brought to Peckham by Dougal, has long been imprinted on the minds of Peckham residents. He therefore easily undercuts the fragile self-confidence of the residents, including their unquestioned, and never consciouslyaffirmed values and patterns of behaviour. All these misled moral values and patterns of behaviour, particularly elaborated through gender interaction, lead to tragic murder and comic evasion, much like the often comic/tragic heroic endings in traditional ballads. Dougal frequently assumes the manner of a concerned counselor, a priest, or a psychiatrist in order to encourage people to confess their unhappiness. The most poignant point Spark makes at the ending of the novel is that if people are too numbly bourgeois (as is Mr. Druce) to doubt their own beliefs, then tragedy will entails. Dougal plays a satirical figure who sees to it that Peckham's residents invent some reasons to justify themselves with their demoralising values. Spark's text evinces an uncompromising moral attitude that foregrounds the emergence of a voice that effectively counters the invented world of morality and the gendered world of traditional ballads.

\section{REFERENCES}

[1] Bloom, Harold. 'Introduction'. Mary Shelley. Ed. Harold Bloom. Modern Critical Views. New York: Chelsea House Publishers, 1985. 1-10.

[2] Christianson, Aileen. 'Certainty and Unease in Muriel Spark's The Ballad of Peckham Rye'. Scottish Women's Fiction, 1920s to 1960s: journeys into being. Eds. Carol Anderson and Aileen Christianson. East Lothian: Tuckwell Press Ltd, 2000. 134-146.

\footnotetext{
${ }^{22}$ Massie, Allan. Muriel Spark. (Edinburgh: The Ramsay Head Press, 1979), p. 30.
} 
[3] ---. 'Muriel Spark and Candia McWilliam: Continuities'. Contemporary Scottish Women Writers. Eds. Aileen Christianson and Alison Lumsden. Edinburgh: Edinburgh University Press Ltd, 2000. 95-110.

[4] Cixous, Hélène. 'Grimacing Catholicism: Muriel Spark's Macabre Farce'. Theorising Muriel Spark: gender, race, deconstruction. Ed. Martin McQuillan. New York: Palgrave, 2002. 204-209.

[5] Gregson, Ian. 'Muriel Spark’s Caricatural Effects'. Essays in Criticism. 55:1.

[6] Grosz, Elizabeth. Sexual Subversions: three French feminists. Sydney: Allen and Unwin, 1989.

[7] Hosmer, Robert. 'An Interview with Dame Muriel Spark'. Salmagundi. (Spring 2005): 127-158.

[8] Kristeva, Julia.Powers of Horror: An Essay on Abjection. Trans. Leon S. Roudiez. New York: Columbia University Press, 1982.

[9] ---. Tales of Love. Trans. Leon S. Roudiez. New York: Columbia University Press, 1987.

[10] Levine, George. 'The Ambiguous Heritage of Frankenstein'. The Endurance of Frankenstein: essays on Mary Shelley's novel. Eds. George Levine and U. C. Knoepflmacher. Los Angeles: University of California Press, 1979 [1974]. 3-30.

[11] Malkoff, Karl. Muriel Spark. New York \& London: Columbia University Press, 1968.

[12] Massie, Allan. Muriel Spark. Edinburgh: The Ramsay Head Press, 1979.

[13] Mellor, Anne. Mary Shelley: her life, her fiction, her monsters. New York: Routledge, 1988.

[14] Moers, Ellen. 'Female Gothic'. The Endurance of Frankenstein: essays on Mary Shelley's novel. Eds. George Levine and U. C. Knoepflmacher. Los Angeles: University of California Press, 1979 [1974]. 7787.

[15] Morris, Pam. Realism. The New Critical Idiom. London and New York: Routledge, 2003.

[16] Punter, David. The Literature of Terror: a history of gothic fictions from 1765 to the present day. London and New York: Longmans, 1980.

[17] Spark, Muriel. The Ballad of Peckham Rye. London: Penguin Books, 1963 [1960].

[18] ---. 'Frankenstein'. Mary Shelley. Ed. Harold Bloom. Modern CriticalViews. New York: Chelsea House Publishers, 1985. 11-30.

Citation: Dr. Lin, Hsin-Ying "Fictionalised Reality? : Interrogating the Validity of Truth in Muriel Spark's The Ballad of Peckham Rye" International Journal of Humanities Social Sciences and Education (IJHSSE), vol 8, no. 7, 2021, pp. 233-248. doi: https://doi.org/10.20431/2349-0381.0807026.

Copyright: (C) 2021 Authors. This is an open-access article distributed under the terms of the Creative Commons Attribution License, which permits unrestricted use, distribution, and reproduction in any medium, provided the original author and source are credited. 